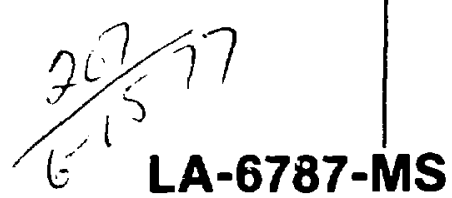

Intormal Report
UC.38

!ssued: April 1977

\title{
Seismic Qualification of Equipment for the TA-55 Plutonium Processing Facility
}

Philip R. Pellette

Elton G. Endebrock

Paul M. Giles

Richard H. Shaw

An Alfirmative Action / Equal Opporlunity Employer 
Printed in the United States of America. Available from National Technical Information Service

U.S. Department of Commerce

5285 Port Royal Road

Springfield, VA 22161

Price: Printed Copy $\$ 4.00$ Microfiche $\$ 3.00$

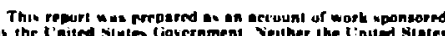

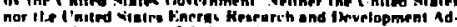

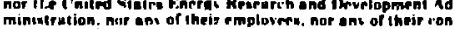

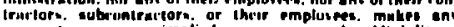

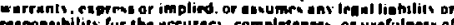

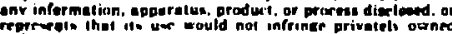

repristo 
SEISMIC QUALIFICATION OF EQUIPMENT

FOR THE TA-55 PLUTONIUM PPOCESSING FACILITY

\author{
by \\ Philip R. Pellette \\ El ton G. Endebrock \\ Paul M. Giles \\ Richard H. Shaw
}

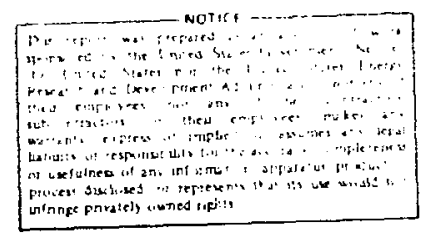

\begin{abstract}
This report discusses the techniques employed by the Los Alamos Scientific Laboratory (LASL) for the seismic qualification of internal equipment for the TA-55 Plutonium Facility. The structural analysis of the plutonium building and critical associated structures was performed by the Architect-Engineer (A-E), and the calculations were checked by LASL.

The specifications and procedures used by LASL produced dramatic improvement in the responses by qualified vendors to the seismic requirements. There was an increase from about a $20 \%$ bid iatio to greater than $90 \%$ because prospective vendors could be competitive without having had previous seismic experience with their equipment.

The equipment seismic qual ification for TA-55 is in compliance with the Code of Federal Regulations, Nuclear Regulatory Commissinn (NRC) Guides, Energy Research and Develoyment Administration (ERDA) Manual Chapters and Appendices, and Institute of Electrical and Electronic Engineers (IEEE) Standard 344.
\end{abstract}

\title{
I . INTRODUCTION
}

The TA-55 Plutonium Processing Facility is being constructed at LASL to accommodate future requirements for plutonium research and component fabrication in support of military, reactor, space power, and materials research programs. Modifications to the existing facilities to comply with the latest heal th and safety criteria were no longer considered feasible. ${ }^{1}$

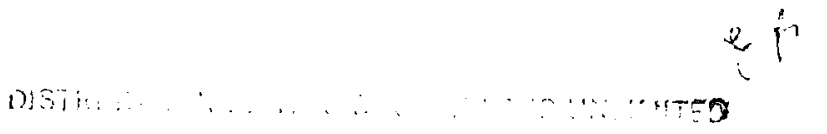


The following factors led to the selection of the site on Pajarito Road for the new tacility.

- Proximity to the radioactive liquid waste treatment facility.

- Minimum impact on continuity of existing programs.

- Adequate area for support functions.

- Adequate natural drainage.

- Isolation from inhabited areas.

- Meteorology and seismology considerations.

Using the latest draft of ERDA's "Minirum Criteria for New Plutonium Facilities" as a guide, the Fluor Corporrtion, Los Angeles, CA, A-E for the facility, began studies to determine the probability of occurrences of natural phenomena in the area, such as earthquakes, and techniques for hardening the facility to withstand such occurrences. The Consulting Firm of Dames and Moore, Santa Barbara, CA, was hired by F?uor Corporation to study the proposed site and verify its acceptability under seismic considerations.

A. Mi nimum Criteria for New PJ utonium Facilities

The criteria of ERDAM Appendix 6301, Part II, Sec. I, were in draft form at the time of this study, but it was considered important to take measures to insure that the new plutonium facility would be in accordance with the intent nf that document. The criteria specif: : the following about seismic design resistance.

- Seismic parameters should be developed for the site, and Design Basis Earthquake (DBI:) and Operating Basis Earthquake (OBE) should be defined.

- Critical sections of the structure should be designed to withstand the DBE.

- Critical systems, such as ventilation, fire protection, and utilities, should be designed to withstand the DBE.

B. Geologic, Hydrologic, and Seismic Investigation

The geologic features within 200 miles of the site and details of the immediate site area were studied. Dames and Moore ${ }^{2}$ concluded that the proposed TA-55 site was suitable for the plutonium processing facility and the risks of future surface faulting or volcanism were minimal. Infrared aerial photographs, field mapping, and a geologic trench dug on the site were used to verify that there were no extensions of faults in the area. 
Based on available data, Dames and Moore reported it was unlikely that earthquake motion greater than Intensity VI has ever been experienced at the site. The largest nearby earthquake of record was the 1918 Cerillos earthquake with an epicenter located approxinately 35 miles to the southeast. Larger intensity earthquakes have been located farther south. However, the geologic and tectonic features of the Rio Grande rift indicate that larger earthquakes may be possible.

Dames and Moore proposed that the plutonium processing facilities be designed for two earthqliake events: an OBE that would assume ground motion at the site of Intensity VII, but less than VIII, and a DBE with motion of Intensity VIII. Figures 1 and 2 illustrate the $O B F$ and $D B E$ response spectra used, which were derived from records of the 1935 Helena, MT, earthquake modified to fit the local dynamic soil properties. The acceleration-time histories from which the spectra were derived accompanied the Dames and Moore report. The DBE acceleration-time histories for the jrincipal axes are show in Figs. 3, 4, and 5 .

C. Seismic Specifications

The Fluor Corporation contracted with Wyle Laboratories, Norco, CA, and Huntsville, $A L$, to generate a seismic specification for systems purchased for critical applications in the plutonium facility. The specification was based on the earthquake shock spectra derived by Dames and Moore, which were translated into test criteria that could be used by equipment manufacturers to qualify equipment by analytical and/or cmpirical techniques.

Wyle Laboratories produced a complete and comprehensive seismic specification that was included as an appendix to the internals package (J-package) specifications." The J-package specifications identified the critical TA-55 systems, but a breakdown to the component level of detail was not included. Several testing options were offered in the seismic specification, including biaxial and uniaxial independent motion in the two principal horizontal and vertical directions. Random motion, complex motion, acceleration-time history, sine beat, decaying sinusoid, and fragility level testing techniques were outlined. The technique of qualification of equipment by a combination of analysis and test was developed.

Wallace/Brown-Olds/Howard $(W / B-O / H)$, a Los Alamos-based construction company, was contracted to purchase and install most of the internal equipme. $t$ 


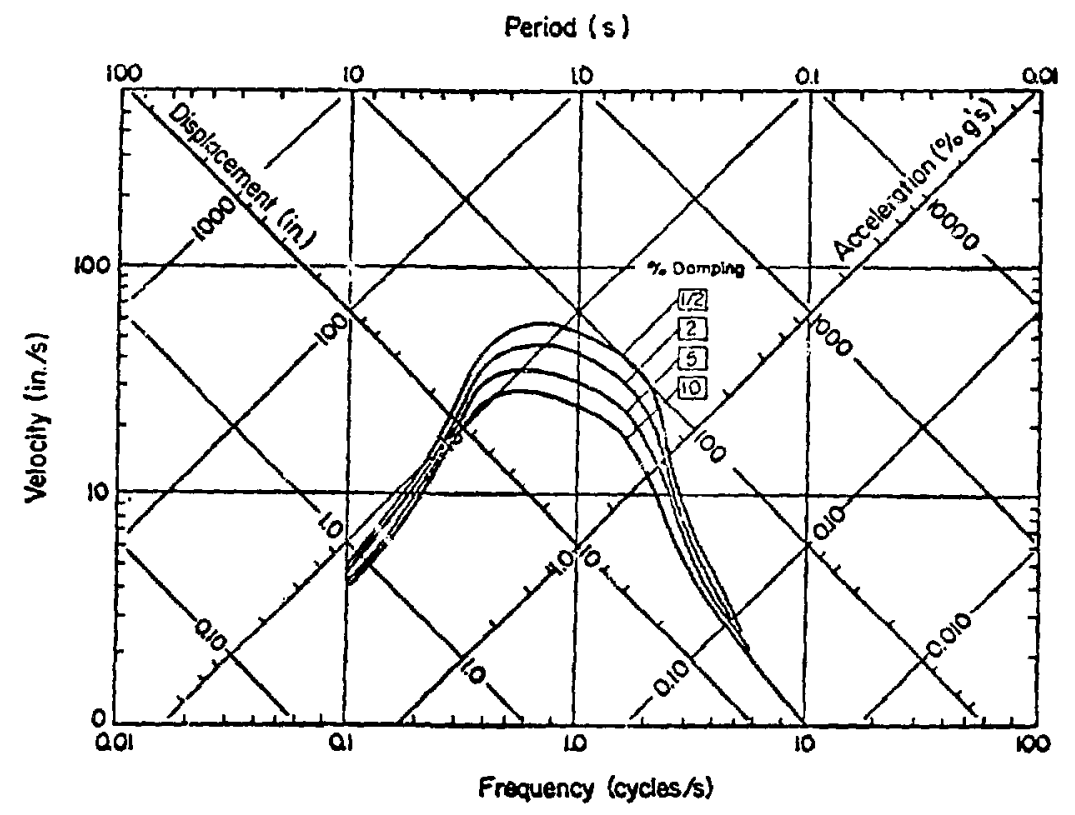

Fig. 1. Recommended smoothed response spectra, OBE.

Period (s )

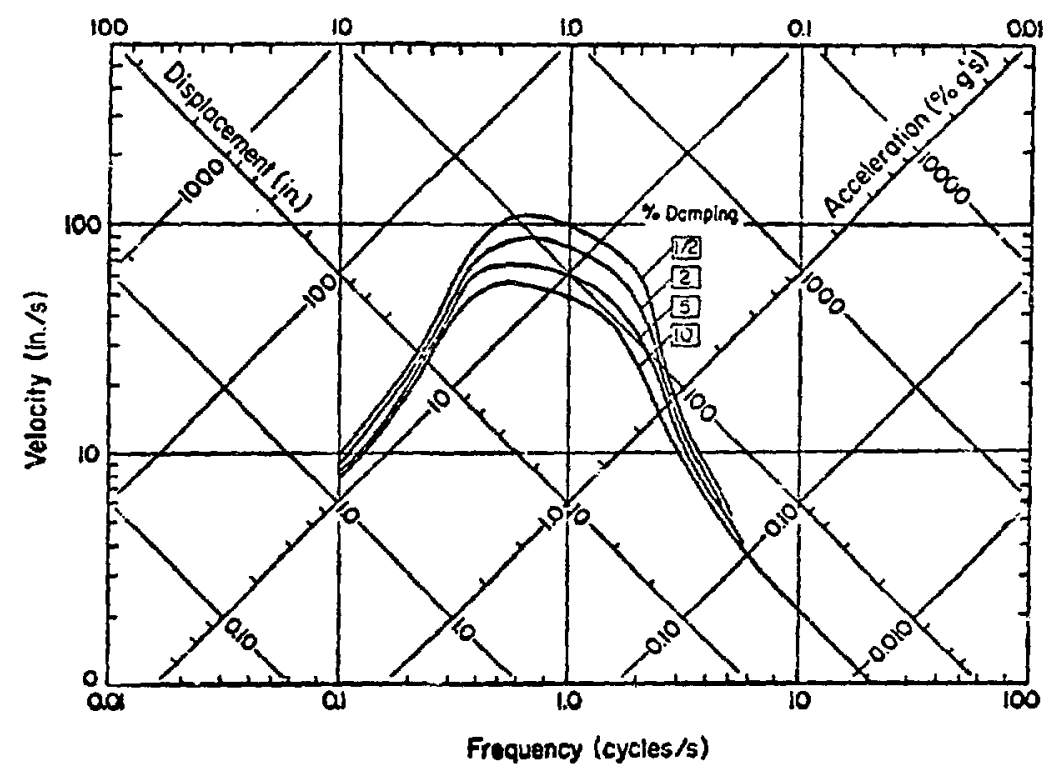

Fig. 2. Recommended smoothed response spectra, DBE. 


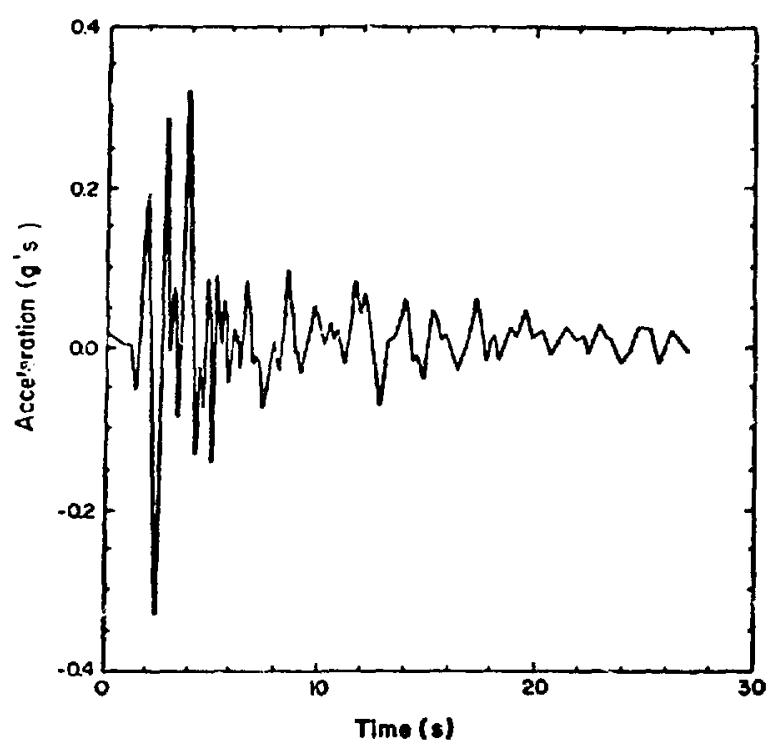

Fig. 3. DBE at Los Alamos, vertical component.

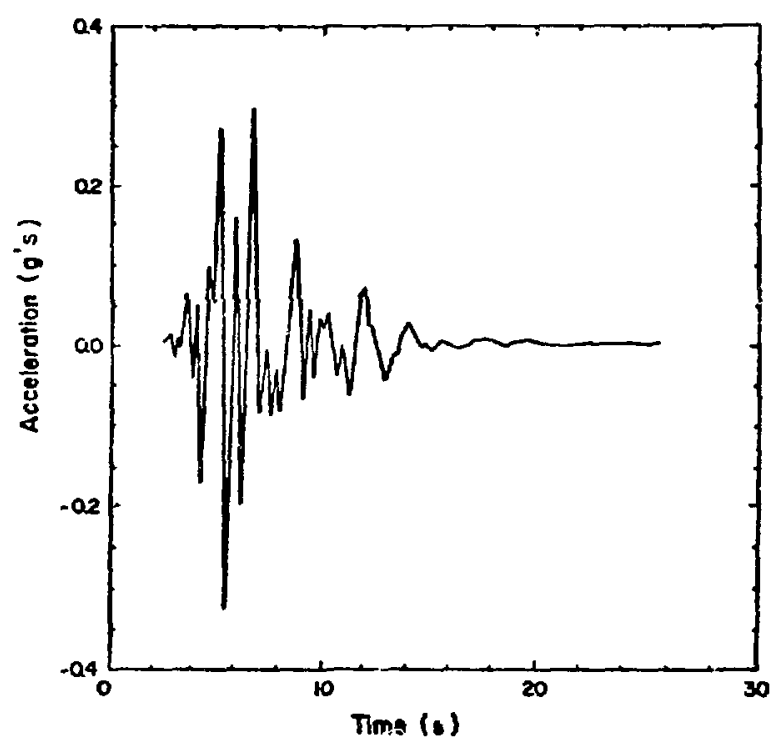

Fig. 4. DBE at ios Alamos, horizontal component No. 1 .

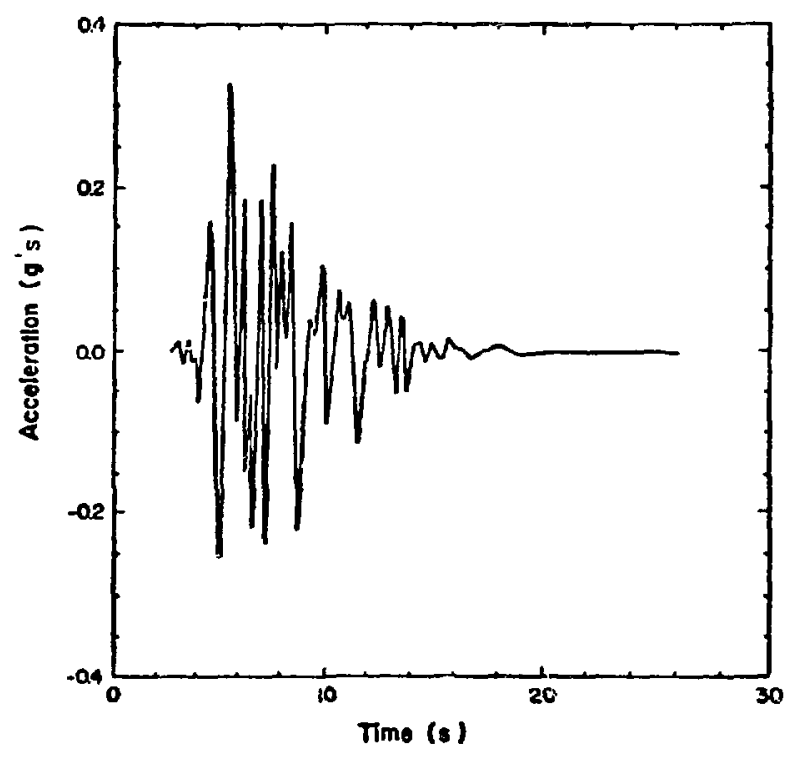

Fig. 5. DBE at Los Alamos, horizontal component No.?. 
in TA-55 per the appropriate drawings. Some equipment was purchased by LASL

as Government-Furnished Equipment (GFE) and installed by $W / B-0 / \mathrm{H}$.

When the Fluor seismic specification was included with the initial Request for Quotation (RFD cocuments to purchase internal TA-55 equipment, the industry reaction was less than desirable. Often vendors simply failed to bid and then responded to lator inquiries by saying that the seismic criteria had "scared them off." Reference 4 outlines the problems encountered in purchasing the diesel-driven fire water pump and scme of the electrical gear. The fire pump KFQ was sent to seven prospective suppliers; two bids were received and both took many exceptions to the seismic reçuirements. Experience purchasing other critical components was similar. Sometimes, where seismic qualification was included in the bid, the qualification cost increased the component cost by several tines.

\section{I. LASL SEISMIC QUALIFICATION APPROACH}

A. Summary

Group WX-4 (previously ENG-6) employed a combination of analytical and test techniques to solve the problem of seismic qualification of TA 55 equipment. Initially, the seismic specification was rewritten ${ }^{5}$ clarifying the seismic requirements to make them comprehensible to the uninitiated vendor, thereby allowing him to bid competitively. A breakdown was performed of each critical system to the critical component level, and a new seismic specification was generated for use with RFQ's. A seismic test facility at White Sands Missile Range (WSMR), White Sands, NM, was modified to reproduce the LASI. ear rhquake motions.

\section{B. Seismic Classifications}

It was evident from the outset that a complete 1 ist had to be made of all components vital to the functioning of the critical systems of TA-55. This was accomplished by thoroughly reviewing the A-E Title III drawings. Items were classified I (DBE) or II (OBE), depending on whether the system must function during and immediately following the larger DBE or must only sustain the smaller OBE. The fire water system, for example, must be qualified for the DBE because a fire and/or earthquake are credible. Many heating and ventilating (HEV) system valves and dampers would be requived to continue operating after the smaller (more probable) $O B E$, thereby reducing the time required to get the 
plant back into operation. These same valves and dampers would not be qualified for the DBE because the building structure is designed so supply containment following the larger earthquake.

Two additional classifications, "operative" and "structural," were assigned to each item. The diesel-driven fire pump, for example, might be required to start and run during a DBE. The electrical fire punp in the same system, however, would only have to maintain structural integrity, thus preventing a large system leak. This difference produced a considerable saving in individual test cost. An operative test usually costs more because a functional check has to be performed before and after the seismic event, or the unit has to be operated throughout the seismic test. For some items, such as the fire pump, the cost of plumbing, vaives, and tanks was appreciable.

The complete 1 ist of critical components and assigned qualification levels were included in the new seismic specification No. 4401-J-1. Appendix $A$ is an excerpt from the iatest version of the specification. C. Multiple Bid Options

A multiple bid quotation form with the following options was written to encourage potential bidders with varying degrees of experience about the performance of their material it the seismic environment.

1. Quotation for equipinent, including test data resulting frcia previous similar applications of the equipment.

2. Quotation for equipment, including analyses or test data to demonstrate that the equipment will meet the accelerationime histories.

3. Quotation for equipment that will be qualified by shake table tests as described in this specification.

4. Quotation for equipment that may not meet the earthcuake conditions outlined in this specification. Any available information shall be included with the quotation.

Bidders had the option to submit alternate quotations on any or all of the four conditions outlined above. With such options, a qualified bidder could remain competitive whether or not he had previous seismic experience. Since using the LASL seismic specification and this quotation form, the vendor response has grown frem 15-20\% to $90-95 \%$.

\section{Seismic Specifications}

A separate specification was written for each component classification mentioned in Sec. II,B. Each was greatly simplified and easier for the 
average equipment supplier to understand. Any past seismic experience with the equipment was declared to be of interest and would aid the purchaser in assessing the behavior of the equipment during an earthquake.

If the supplier selected to qualify his equi ument by test, either the smooth response spectra or the acceleratisn-time histories could be used, and both were presented with the specification. As a sample, the recomended specification for the Class I Operative Equipment is shown in Fig. 6.

Note that, although the new specification offered the supplier more options for bidding and qualification, no reduction in the seismic levels required to be sustained for qualification was suggested or tolerated. With this approach, some of the burden for seismic qualification could be shared by the purchaser at an appropriate reduction in equipment cost.

\section{SEISMIC QUALIFICATION BY TESTING}

A. WSMR

Because the new approach to seismic bid options encuuraged vendors to quote without concern for seismic qualification, it was necessary to subject various components to the TA-55 seismic spectra. A survey of local test facilities was undertaken, which included LASL; Kirtland Air Force Base, Albuquerque, NM; Sandia Corporation, Albuquerque, NM; and WSMR. At WSMR, it was learned that equipment was available with roughly the required capabilities, that is, a controlled test table large enough to support several tons of equipment and move in the low-frequency $(0-100 \mathrm{~Hz})$ range with large displacements $(2-10 \mathrm{in}$.). This equipment was located at the "300-K" and "LC-33" test sites, and was formerly used to test missiles, warheads, associated trailers, and shipping containers. The facilities were centrally controlled with modern, sophisticated electronic instrumentation. Fortunately, the workload at these sites was compatible with our test schedule, and a more complete study verified that this equipment could reproduce the motions required by the TA-55 earthquake spectra.

WSMR submitted a proposal to LASL to modify the 300 - $K$ test site for the earthquake testing of equipment. It includer the assembly of separate horizontal and vertical test tables, sized to accept all the anticipatc i items except the emergency generator and plant air compressors. These units would be considered an anomaly to the normal test requirements. All the other equipment, 
Class I Operative Equipment

The equipment will be installed in a facility located in a potentially seismic area. The smooth response spectra shown in Fig, 2 have been generated from a seismic analysis of the site and buildings to represent the Safe Shutdown Earthquake (SSE), also referred to as the Design Basis Earthquake (DBE). The equipment would be reguired to remain operative during and immediately following such an event. Preference will thus be given to those suppliers who can show that their equipment, supported as the supplier recommends that it can be supported in the facility, will continue to function normally during and immediately after being subjected to the SSE.

It is anticipated that some suppliers will have test data or analyses available, resulting from previous similar applications of their equipment. These vendors are encouraged to submit the available information for consideration with their proposals. The information can then be used to determine what level of qualification testing or analysis remains to be performed by the purchaser prior to installation of the equipment.

Three components of ground acceleration have been generated to represent this SSE and are shown in Figs. 3, 4, and 5. The acceleration-time histories of the three components are available in digitized form on computer cards and may be obtained on request. Suppliers may demonstrate the performance of their equipment by rational analysis, test results, or a combination of both. Either the response spectra shown in Fig. 2 or these time-histories nay be used in this demonstration.

If suppliers wish to gualify their equipment by test, the time-histories shown in Figs. 3, 4, and 5 should be applied simultaneously if a triaxial shaking table is available. If a biaxial shaking table is used, the horizontal components should be increased in intensity by $20 \%$ and applied to the principal horizontal axes of the equipment, in turn, simultaneously with the vertical component. If a uniaxial shaking table is used, the components should be increased in intensity by $30 \%$ and applied to each principal axis of the equipment, in turn. In testing, the SSE should be preceded by three OBEs; ar OBE has onehalf the acceleration intensity of the SSE. Testing costs should be indicated in the bid cost breakdown.

Suppliers who cannot demonstrate the performance of their equipment for the SSE should supply whatever evidence they may have that would assist the purchaser in assessing the behavior of their equipment during an earthguake. If available, they should supply the natural frequencies and associated damping factors of the fundamental mode of the equipment in the vertical and in the two principal horizontal directions. They should also provide, if available, the highest acceleration at which their equipment will continun to operate, at various exciting frequencies (fragility test results).

Fig. 6. Sample of the reconmended specification for the Class I Operative Equipment. 
from small 1-in. valves to the entire diesel-driven fire pump, was included in the WSMR planning. All existing test equipment at WSMR, as government equipment, incurs no charge to the user, and a nominal labor charge is made for work performed by the WSMR civilian personnel ( $\$ 13$ per man-hour for FY 1977) during setup and functional or seismic testing.

The modifications to the WSMR $300-\mathrm{K}$ site were accomplished and the facility now has the following capabilities.

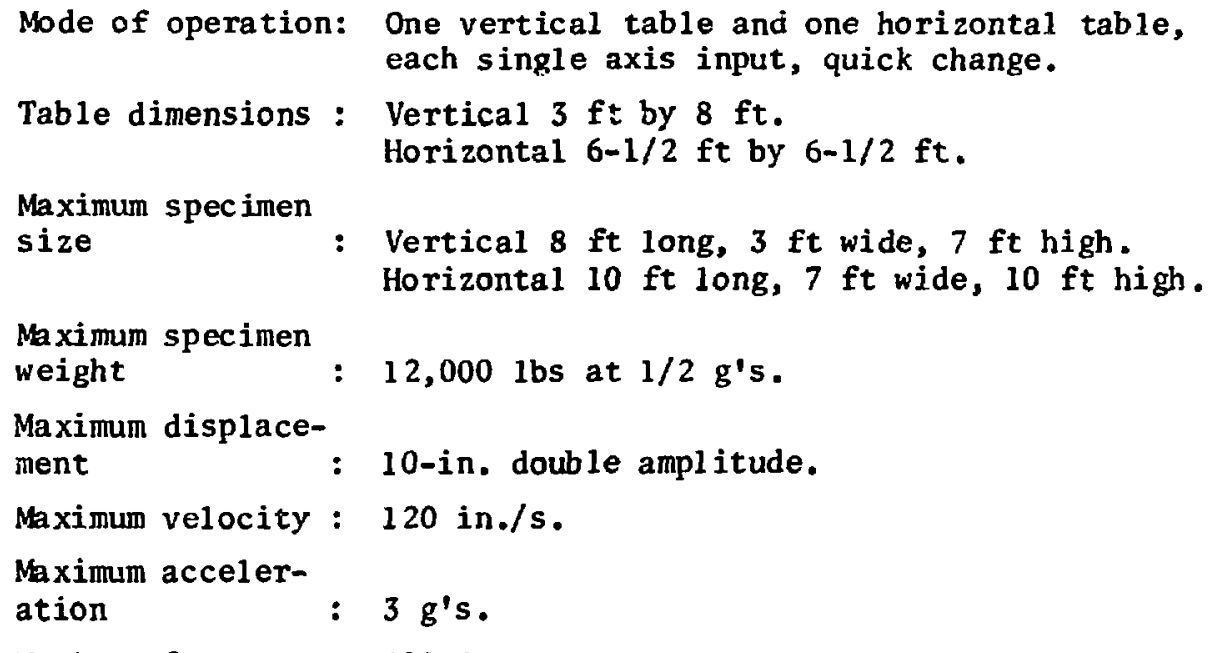

Maximum frequency: $500 \mathrm{~Hz}$.

Al though the 300-K area is presently providing the LASL OBE and DBE acceleration-time histories, adjustment to other levels and modes of testing could be easily accomplished. A similar capability of low-frequency/high-displacement testing exists at the LC-33 site, where the maximum specimen weight is $80,000 \mathrm{lbs}$ at $0.5 \mathrm{~g}$ 's, and the maximum displacement is 4-in, double amplitude. B. Wyle Laboratories, Huntsville, $A L_{\text {, }}$ and Norco, CA, Facilities

Some of the vendors chose to supply seismic certification with their submittals, and their quotations reflected test programs to be conducted at the Wyle test facilities. Both Wyle locations offer independent dual-axis shaking tables with complete control and measurement instrumentation. The I-T-E emergency substation units were tested at the Wyle facility, Huntsville, $A L$; the multiplexers and the uninterruptible power supply were tested at Norco, CA, 


\section{Earthquake Enrineering Research Center (EERC), Richmond, CA}

The emergency generator was successfully tested during the week of January 3, 1977. The diesej-driven unit, associated batteries, and controller, were subjected to three $\mathrm{OBE}$ and one $\mathrm{DBE}$ intensity earthquake motions in two axes (vertical and horizontal), simultaneously. The unit was then rotated $90^{\circ}$ on the table and the test was repeated. A sine sweep between 1 and $20 \mathrm{~Hz}$ at an intensity of $0.5 \mathrm{~g}^{\prime} \mathrm{s}$ was introduced in each principal axis independently to determine the natural frequencies of the assembly and components. The generator was operated under a simulated load bank prior to and following each series of tests.

The central feature of the EERC laboratory is the $20-\mathrm{ft}$ by $20-\mathrm{ft}$ shaking table used to study the earthquake response behavior of test specimens vibrating at amplitudes large enough to cause inelastic deformations. The table can move in the vertical and in one horizontal degree-of-freedom. It may be used to subject structures weighing up to 100,000 lbs to horizontal motions of about twice the intensity of the north-south component of the El Centro, CA (1940) earthquake, and simultaneously, to vertical motions about twice the intensity of that same earthquake.

IV. SEISMIC QUALIFICATION BY ANALYSIS

A. Structural Characteristics

The structural characteristics of the TA-55 facility are such that it acts as a rigid body. The significance of this characteristic is that the site design response spectra apply to all locations within the facility; hence, the site response spectra are also used to design and analyze the equipment within the facility. The site design response spectra show that no amplification occurs for frequencies above $7 \mathrm{~Hz}$. Equipment whose lowest natural frequency exceeds $7 \mathrm{~Hz}$ may be qualified by verifying that it is not overstressed by loads produced by the maximum expected site acceleration of $0.33 \mathrm{~g}$ 's B. Equipment Analys is

Each piece of equipment that was qualified by analysis was modeled in a way that appeared to be the most appropriate for that particular unit. The lowest natural frequency was estimated, and it always exceeded $7 \mathrm{~Hz}$. The inertial loads were based on $0.33 \mathrm{~g} ' s$ and were considered to be static. 
Stresses and/or deflections were compled and compared to acceptable 1 imits. If the acceptable limits were exceeded, modifications were introduced that would bring the stresses and/or deflectiuns within 1 imits. Special attention was given to connections and to floor mounts to insure that they are adequate to resist potential earthquake loads.

V. DOCUNENTATION AND REPORTING

A. Design Review Board

The documentation of each step in the seismic qualification of equipment was an important aspect of the problem. As part of the LASL Engineering Department's Quality Assurance Program for the construction phase of the TA-55 facility, a Design Review Board was estailished consisting of specialists in specific portinns of design and construction. Each document generated throughout the program that affected design or represented a change from a preset configuration was circulated through the board members for approval and verification that such changes were acceptable. Some documents that were routed in this manner were:

- List of critical seismic equipment with classifications,

- Seismic specifications,

- Vendor submittals,

- Design changes with drawings,

- Seismic test plans, and

- Seismic test reports.

The review of vendor submittals was a positive input to the seismic qualification picture. Some suppliers had misunderstandings regarding the seismic criteria, many of which were resolved by telephone conversations. By attending prebid conferences with vendors, it was also possible to explain details of the seismic specifications that were confusing to those who were facing them for the first time. Soon it was found that more vendors were becoming familiar with the terminology and requirements of the seismic criteria. Specific design recommendations, such as bracing for the overhead sprinkler system, were introduced early in the design phase and were implemented during original plumbing installation, thus avoiding expensive retrofit. 


\section{B. Shipping Documents}

A standardized form was generated that supplied shipping information and details about receiving inspections for each major equipment item. Mode1, part identification, and carrier name were included to assist in keeping track of the equipment, some of which was government-furnished, and some contractorsupplied $(W / B-O / H)$.

C. Test Plan

A test plan was composed prior to each seismic test and circulated through the Design Review Board to insure compliance with design requirements. The plan contained a Work Order form that was designed to inform test facility personnel of specific test sequences, instrumentation, and photographic coverage required. A generalized Seismic Qualification Test Plan presented the program requirements. The test plan gave details of the functional checks required to verify test article performance following the seismic event. The test plan used for the emergency generator set is shown in Appendix $B$.

\section{COST OF SEISMIC QUALIFICATION}

A. Cost Summary

The total cost of the seismic qualification program for TA-55, through August 1976, is sumnarized and presented here, along with a projection of the cost of performing the remaining work. It is assumed that the testing workload is in the process of cresting and will continue at a diminishing rate through 1977 and the first half of 1978. As construction progresses, it is anticipated that some analyses will be required to verify the seismic resistance of components after installation, since the "as built" configuration of critical systems and subsystems must be qualified. 
Title II Seismic Charges (FY 1975) (including specification writing,

drawing review, and initial test)

FY 1975 GFE Equipment Qualification

FY 1975 Contractor Equipment Qualification

FY 1976 GFE Equipment Qualification

FY 1976 Contractor Equipment Qual ification

FY 1976T GFE Equipment Qualification

FY 1976T Contractor Equipment Qualification
$\$ 18,000$

$\begin{array}{r}4,000 \\ 8,400 \\ \hline 50,000 \\ 80,000 \\ \hline 4,000 \\ 17,000 \\ \hline\end{array}$

$\$ 18,000$

12,400

$13 C, 000$

21,000

$\$ 181,400$

Total Seismic Qualification

The numbers reflect all charges, including test engineering support, test coordination, vendor submittal reviews, contractor equipment shipping coordination, and final seismic test report coordination. The following cost figures are projected to occur before completion of the program.

FY 1.977 GFE Equipment Qualification

FY 1977 Contractor Equipment Qualification

FY 1978 GFE Equipment Qualification

FY 1978 Contractor Equipment Qualification

Projection to Program Completion
$\$ 16,000$

$-120,000$

$\$ 136,000$

12,000

64,000

Projection to Program Completion $\frac{76,000}{\$ 212,000}$




\section{REFERENCES}

1. "U. S. Atomic Energy Commission Environmental Statement, Plutonium Facility, Los Alamos Scientific Laboratory, New Mexico," WASH-1506 (January 1972).

2. "Report of Geologic, Foundation, Hydrologic and Seismic Investigation, Plutonium Processing Facility, Los Alamos Scientific Laboratory, Los Alamos, New Mexico, for U. S. Atomic Energy Commission," by Dames and Moore, Job Number 0651-120-02 (November 29, 1972).

3. "Technical Specifications for Plutonium Building (Internalsj, DP Site Plutonium Processing Facility, Site TA-55, Los Alamos, New Mexico," prepared by Fluor Engineers and Constructors, Inc.

4. Personal comminication, K. L. Walters, CADP, LASL, to John Anderson, CMB-11, LASL, June 13, 1974 .

5. "Specification No. 4401-J-1 Plutonium Building (Internals), Division 1D Seismic Qualification of Systems and Equipment," prepared by WX-4, LASL, revised July $7,1975$.

\section{APPENDIX A}

EQUIPMENT TABLE

Excerpt from Specification No. 4401-J-1 Plutonium Buildings (Internals) Division ID - Seismic Qualification of Systems and Equipment

(Revised July 7, 1975)

The following table contains a break-out of each piece of equipment contained in the critical seismic systems. The classification column lists the seismic classification. This made it possible for the purchasing agent to attach the appropriate specification to each equipment item.

FIRE SERVICE WATER SYSTEM

Number

P-703 (706)

$S P-116$

SP- 118

PCV-701 (704)

PI-701 (704

H-701 A, B (H-704 A, B)
Description

Jockey punp

Check val ve

Gate valve

Back pressure regulator

Pressure gauge

Water heaters

\section{Classification}

Class I (St ructural)

Class I (Operative)

Class I (Structura1)

Class I (Structura1)

Class I (Structura1)

Class I (Structura1)*

*Seismic qualification by design. 


\begin{tabular}{|c|c|c|}
\hline Number & Description & Classification \\
\hline \multirow[t]{2}{*}{$V-701 \quad(704)$} & Water storage tank & $\begin{array}{c}\text { Class I (Structural)* } \\
(\text { P Package) }\end{array}$ \\
\hline & $\begin{array}{l}8-\text { in. Valve (between } 8-\text { and } \\
12 \text {-in. lines) }\end{array}$ & Cuass I (Operitive) \\
\hline HV $-701 \quad(711)$ & Manual butterfly valve & Class I (Operative) \\
\hline$H V-702 \quad(712)$ & Manual butterfly valve & Class I (Operative) \\
\hline $\mathrm{HV}-707 \quad(710)$ & lianual butterfly valve & Class I (Operative) \\
\hline $\mathrm{HV}-704(714)$ & Manual butterfly valve & Class I (Operative) \\
\hline$P-701 \quad(705)$ & Diesel-driven pump & Class I (Operative) $t$ \\
\hline HV-706 (709) & Manual butterfly valve & Class I (Operative) \\
\hline P-702 (704) & Electric fire pump & Class I (Structural) $\dagger$ \\
\hline \multirow[t]{4}{*}{ P-701 CR (705 CR) } & Diesel pump controller & Class I (Operative) $t$ \\
\hline & Sprinkler systems & Class I (Operative) \\
\hline & $\begin{array}{l}\text { Associated piping, including } \\
\text { underground loop }\end{array}$ & Class I (Structural)* \\
\hline & $\begin{array}{l}\text { Associated valves in under- } \\
\text { ground loop }\end{array}$ & Class I (Operative) \\
\hline
\end{tabular}

AIR SAMPLING (INTEGRATING) SYSTEM (EMERGENCY STACK MONITOR ONLY)

\begin{tabular}{|c|c|c|}
\hline Number & Description & Classification \\
\hline$J-4243,4(5)$ & $\begin{array}{l}\text { Air circulating pump } \\
\text { w/electric motor }\end{array}$ & Class I (Operative) \\
\hline & Mounting for air pump & Class I (Structura1)* \\
\hline & Air plumbing (probe/pump) & Class I (Structural)* \\
\hline & Air pump wiring (pump/battery) & Class I (Operative) \\
\hline & Air pump on/off trigger & Class I (Operative) \\
\hline & Air sampling probe & Class I (Structural) \\
\hline & Battery and inverter & Class I (Operative) \\
\hline \multicolumn{3}{|l|}{ EMERGENCY LIGHTING } \\
\hline \multirow[t]{3}{*}{ Number } & Description & Classification \\
\hline & $\begin{array}{l}\text { Light and battery unit } \\
\text { w/triggering system }\end{array}$ & Class I (Operative) \\
\hline & Mounting & Class I (Structural)* \\
\hline
\end{tabular}

* Seismic qualification by design.

+ Furnished by LASL (GFE). 
HYDROGEN AND METHANE GAS (INSIDE PU BUILDING)

$\frac{\text { Number }}{\mathrm{J}-0086} \quad \frac{\text { Description }}{\text { Hydrogen and methane gas lines }} \frac{\text { Classification }}{\text { Class II (Structura 1)* }}$

GLOVE AND DROF BOX SUPPORTS

\begin{tabular}{ll} 
Number & \multicolumn{1}{c}{ Description } \\
$\mathrm{J}-9900$ & New drop box supports \\
$\mathrm{J} 4-9900$ & Existing (moved from o1d \\
& DP drop box supports)
\end{tabular}

PROCESS AND INDUSTRIAL WASTE (OUTSIDE PU BUILDING)

Number

J-0086

Frame 4

Description

4 ea. 3/4-in. Ball valves
4 ea. 2-in. Ball valves

4 ea. 1-1/2-in. Ball valves

2 ea. 2-in. Pipe

2 ea. 1-1/2-in. Pipe

2 ea. $1-1 / 2-i n$. to $3 / 4-i n$. Tee reducer

4 ea. 3/4-in. Pipe

2 ea. 2-in. to 3/4-in. Tee reducer

NI-CARBONYL GAS SYSTEM

Number

$\mathrm{J}-0122$

Det-77

HYDROGEN FLUORIDE

Number

Description

Piping

Description

Piping

CONTINUOUS AIR MONITORING (CAMS)

Number

Description

Stack Monitors

2 ea. Cam units

2 ea. Pumps

\section{Classification}

Class II (Structural)*

Class II (Structural)*†

\section{Classification}

Class II (Operative)*

Class II (Operative)*

Class II (Operative)*

Class II (Structura1)*

C.lass II (Structural)*

Class II (Structura1)*

Class II (Structura1)*

Class II (Structural)*

Classification

Class II (Structural)*

Classification

Class II (Structural)*

\section{Classification}

Class I (Operative)

Class I (Operative)

* Seismic qualification by design.

+ Furnished by LASL (GFE) . 
Number

Description

C.lassification

Area Monitors

4 ea. Cam units,

Class II (Operative)

emergency power

4 ea. Pumps

Class II (Operative)

DATA ACQUISITION SYSTEM

Number

Description

Classification

Multiplexing System

Field Multiplex unit

Class I (Operative)

Cable and wire

Class I (Operative)†

Cencral control unit

Class I (Operative) $\dagger$

Control room multiplex

Class I (Operative)t

Data Logger System

Computer processing unit

Class I (Operative)†

Extended memory

Class I (Operative)

Disks

Class I (Operative)t

Hard copy terminal

Class I (Operative)t

Printer plotter

Class I (Operative) $\dagger$

Magnetic tape

Class I (Operative)t

Interprocessor communication

Class I (Operative) $\dagger$

Cabling

Class I (Operative)t

Support stand

Class I (Structural) f**

Pedestal floor

Class I (Structura 1)

COMPRESSED AIR SYSTEM

Number

Description

Classification

C-602A, B, C

3 ea. Compressors

Class I (Operative)

J-0083, J-0086

3 ea. Control panels

Class I (Operative)

E-605A, B, C

3 ea. Aftercoolers

Class I (Operative)

V-611

Air receiver

Class I (Operative)

ME-617

Air dryer

Class I (Operative)

PCV-211

Isolation valve

Class I (Operative)

* Seismic qualification by design.

+ Furnished by LASL (GFE). 
Number

Description

2 ea. Remote pressure switches

Emergency cooling valves

Associated piping

EMERGENCY POWER SYSTEM

Number

G-612

(Spec. J-1,

Div. 15F)

G-612-VI

V-609

G-612-P1

$\mathrm{EE}-635$

EE -637

EE -660
Description

Engine generator unit

Control panel (generator)

Air bottle starting unit

Battery starting unit

200-gal Day tank

2500-gal Underground tank

Fuel pump

Piping system

Air intake and cooling unit

Generator building structure

Electrical feeders

Transformers (north and south)

Panel boards (north and south)

Station batteries and chargers

Station batteries and chargers

Station batteries and chargers

Battery Banks

Batteries

Racks

Connectors

Control Panel (Dual)

Inverter (solid state)

Charger (converter)

Reiays

Panel Board (Distribution)

Relays

Load shedding, timers, etc.

\section{Classification}

Class I (Operative)

Class I (Operative)

Class I (Structural)*

Class I (Operative)

Class I (Operative)

Class I (Operative)

Class I (Operative)

Class I (Structural)*

Class I (Structural)*

Class I (Operative)

Class I (Structural)*

Class I (Operative)

Class I (Structura 1)*

Class I (Structural)*

Class I (Operative)

Class I (Operative)

Class I (Operative)

Class I (Operative)

Class I (Operative)

Class I (Operative)

Class I (Stmuctural)

Class I (Operative)

Class I (Operative)

Class I (Operative)

Class I (Operative

Class I (Operative)

Class I (Operative)

* Seismic qualification by design. 
Number

Description

Classification

Distribution System

Multiple feeders with separate lines and breakers for

Class I (Operative)* each load

HEATING AND VENTILATING SYSTEM

(Spec. J-1, Div. 15B, Drawings J-3243, J-3244)

Number

Description

Classification

Zone 2 Supply (North)

$J-3243$

Duct (inlet to valve)

Class I (Structura1)

HCV -832

Shutoff valve

Class I (Operative)

$\mathrm{HY}-832$

Activator, shutoff valve

Class I (Operative)

Filter plenum

C1ass II (Structura1)*

HV-809A, B

2 ea. Blowers

Class II (Operative)

CP-814

Control panel, controilers, and sensors

Associated ductwork

Class II (Structura])*

Zone 3 Supply (North)

$J-3243$

HCV -833

HYY -833

HV -840

CP-814

$\mathrm{J}-3244$

$\mathrm{HCV}-882$

$\mathrm{HY}-\mathbf{8 8 2}$

HV-810A, B

CP -824
Duct (inlet to valve)

Shutoff valve

Actuator, shutoff valve

Filter plenum

Blower

Control panel, controllers, and sensors

Associated ductwork

Zone 2 Supply (South)

Duct (inlet to valve)

Shutoff valve

Actuators, shutoff valve

Filter plenum

2 ea. Blowers

Control panel, controllers, and sensors

Associated ductwork
Class I (Structura1)*

Class I (Operative)

Class I (Operative)

Class II (Structura1)*

Class II (Operative)

Class I (Operative)

Class II (Structura1)*

Class I (Structura1)*

Class I (Operative)

Class I (Pperative)

Class II (Structural)*

Class II (Operative)

Class I (Operative)

Class II (Structura1)*

* Seismic qualification by design. 


\begin{tabular}{|c|c|c|}
\hline Number & Description & Classifioation \\
\hline & Zone 3 Supply (South) & \\
\hline $\mathrm{J}-3244$ & Duct (inlet to valve) & Class I (Structural)* \\
\hline $\mathrm{HCV}-883$ & Shutoff valve & Class I (Operative) \\
\hline \multirow[t]{2}{*}{ HY -883} & Actuators, shutoff valve & ilass I (Operative) \\
\hline & Filter plenum & Class II (Structura!)* \\
\hline HV -841 & Blower & Class II (Operative) \\
\hline \multirow[t]{3}{*}{$C P-824$} & $\begin{array}{l}\text { Control panel, controllers, } \\
\text { and sensors }\end{array}$ & Class I (Operative) \\
\hline & Associated ductwork & Ciass II (Structural)* \\
\hline & $\begin{array}{l}\text { Zone } 2 \text { Recirculation (North) } \\
\text { (Pu-239 Wing) }\end{array}$ & \\
\hline$J-3243$ & Plena & Class II (Structural)* \\
\hline HV -803 & Blower & Class II (Operative) \\
\hline HV -804 & Blower & Class II (Operative) \\
\hline$H V-838$ & Shutoff damper & Class II (Operative) \\
\hline$H Y-838$ & Actuator, shutoff damper & Class II (Operative) \\
\hline HV -839 & Shutoff damper & Class II (Operative) \\
\hline$H Y-839$ & Actuator, shutoff dam Jar & Class II (Operative) \\
\hline \multirow[t]{3}{*}{$\mathrm{CP}-817$} & $\begin{array}{l}\text { Control panol, controllers, } \\
\text { and sensors }\end{array}$ & Class I (Operative) \\
\hline & Associated ductivork & Class Il (Structural)* \\
\hline & $\begin{array}{l}\text { Zone } 2 \text { Recirculation (North) } \\
\text { (Pu-238 Wing) }\end{array}$ & \\
\hline$J-3243$ & Plena & Class II (Structural)* \\
\hline $\mathrm{HV}-801$ & Blower & Class II (Operative) \\
\hline$H V-802$ & Blower & Class II (Operative) \\
\hline$H V-837 A$ & Shutoff damper & Class II (Operative) \\
\hline HY $-837 A$ & Actuator, shutoff damper & Class II (Operative) \\
\hline $\mathrm{HV}-837 \mathrm{~B}$ & Shutciff damper & Class II (Operative) \\
\hline$H Y-837 B$ & Actuator, shutoff damper & Class II (Operative) \\
\hline \multirow[t]{2}{*}{ CP-818 } & $\begin{array}{l}\text { Control panel, controllers, } \\
\text { and sensors }\end{array}$ & Class I (Operative) \\
\hline & Associated ductwork & Class II (Structura I)* \\
\hline
\end{tabular}

* Seismic qualification by design. 


\begin{tabular}{|c|c|c|}
\hline \multirow[t]{2}{*}{ Number } & Description & Classification \\
\hline & $\begin{array}{l}\text { Zone } 2 \text { Recirculation (South) } \\
\text { (Recycle) }\end{array}$ & \\
\hline$J-3244$ & Plena & Class II (Structura $)^{*}$ \\
\hline$H V-807$ & Blower & Class II (Operative) \\
\hline $\mathrm{HV}-808$ & Blower & Class II (Operative) \\
\hline $\mathrm{HV}-\mathbf{8 8 8}$ & Shutoff damper & Class II (Operative) \\
\hline HY $-\mathbf{8 8 8}$ & Actuator, shutoff damper & Class II (Operative) \\
\hline HV- 889 & Shutoff damper & Class II (Operative \\
\hline HY -889 & Actuator, shutoff damper & Class II (Operative) \\
\hline \multirow[t]{3}{*}{$\mathrm{CP}-826$} & $\begin{array}{l}\text { Control panel, controllers, } \\
\text { and sensors }\end{array}$ & Class I (Operative) \\
\hline & Associated ductwork & Class II (Structural)* \\
\hline & $\begin{array}{l}\text { Zone } 2 \text { Recirculation (South) } \\
\text { (Metal Fabrication) }\end{array}$ & \\
\hline$J-3244$ & Plena & Class II (Structural)* \\
\hline$H V-805$ & Blower & Class II (Operative) \\
\hline$H V-806$ & Blower & Class II (Operative) \\
\hline$H V-887 A$ & Shutoff damper & Class II (Operative) \\
\hline$H Y-887 A$ & Actuator, shutoff damper & Class II (Operative) \\
\hline $\mathrm{HV}-887 \mathrm{~B}$ & Shutoff damper & Class II (Operative) \\
\hline hiY-887B & Actuator, shutoff damper & Class II (Operative) \\
\hline \multirow[t]{3}{*}{$\mathrm{CP}-821$} & $\begin{array}{l}\text { Control panel, controllers, } \\
\text { and sensors }\end{array}$ & Class I (Operative) \\
\hline & Associated ductwork & Class II (Structural)* \\
\hline & Zone 2 Bleed-off (South) & \\
\hline \multirow[t]{2}{*}{$J-3244$} & 2 ea. Filter plena & Class I (Structura1)* \\
\hline & $\begin{array}{l}\text { Ducting (filter plena to } \\
\text { stack) }\end{array}$ & Class I (Structura1)* \\
\hline$F A-822 A$ & Blower & Class I (Operative) \\
\hline$F A-822 B$ & Blower & Class I (Operative) \\
\hline$F A-823$ & Blower & Class I (Operative) \\
\hline $\mathrm{CP}-827$ & $\begin{array}{l}\text { Control panel, controllers, } \\
\text { and sensors }\end{array}$ & Class I (Operative) \\
\hline $\mathrm{HV}-857$ & Damper & Class II (Operative) \\
\hline $\mathrm{HY}-857$ & Actuator & Class II (Operative) \\
\hline
\end{tabular}

* Seismic qualification by design. 


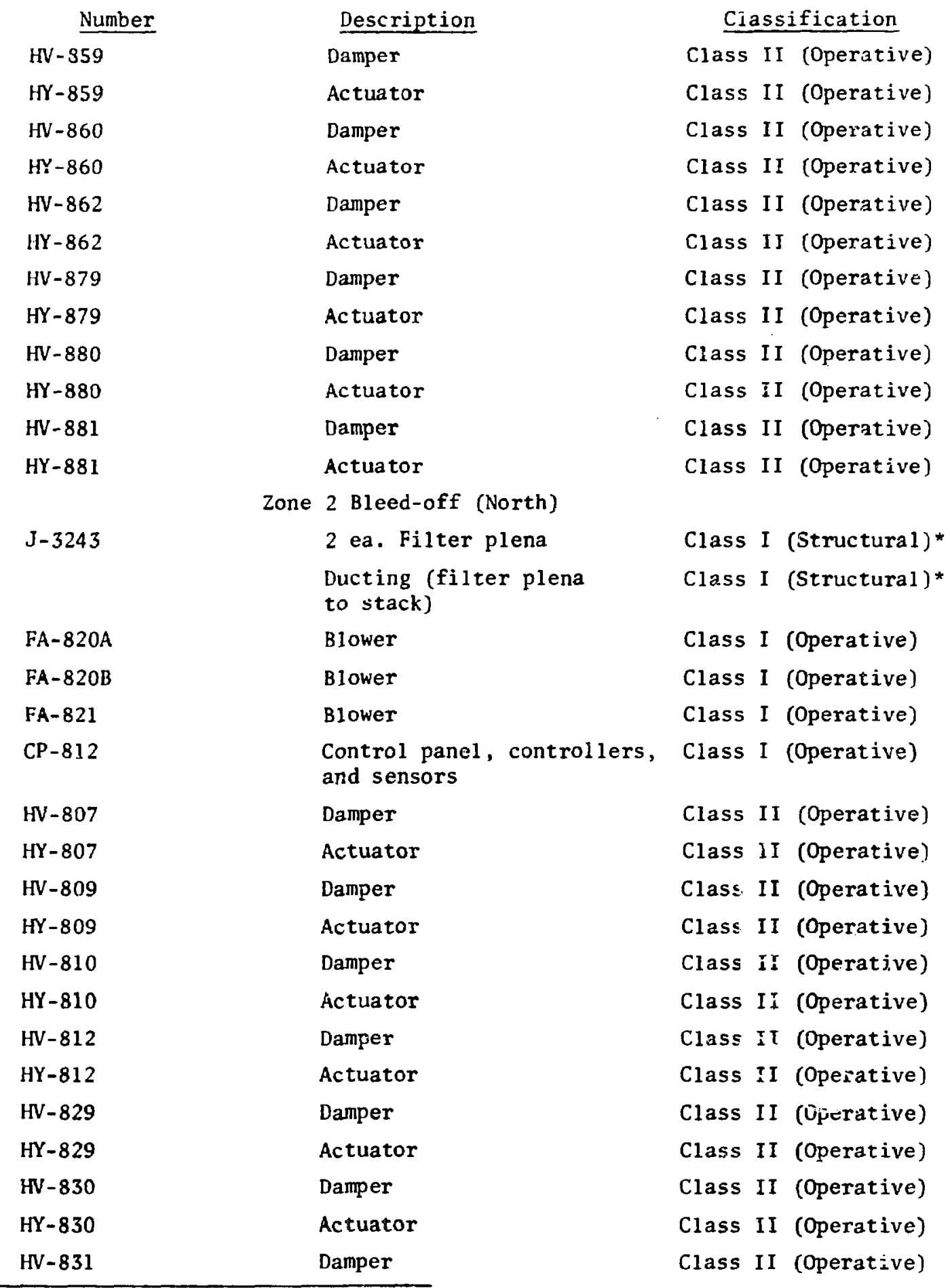

* Seismic qualification by design. 


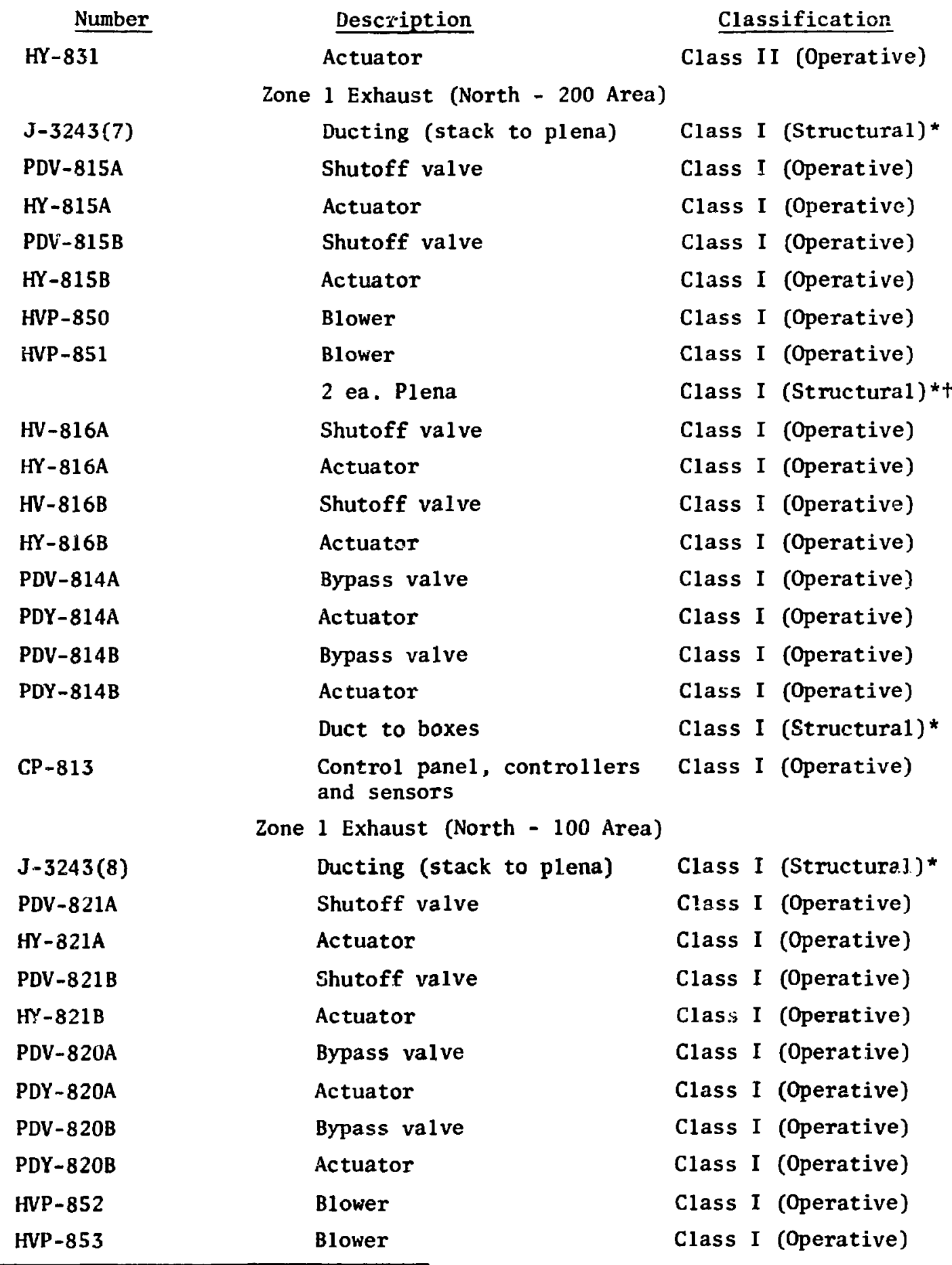

* Seismic qualification by design.

+ Furnished by LASL (GFE) 


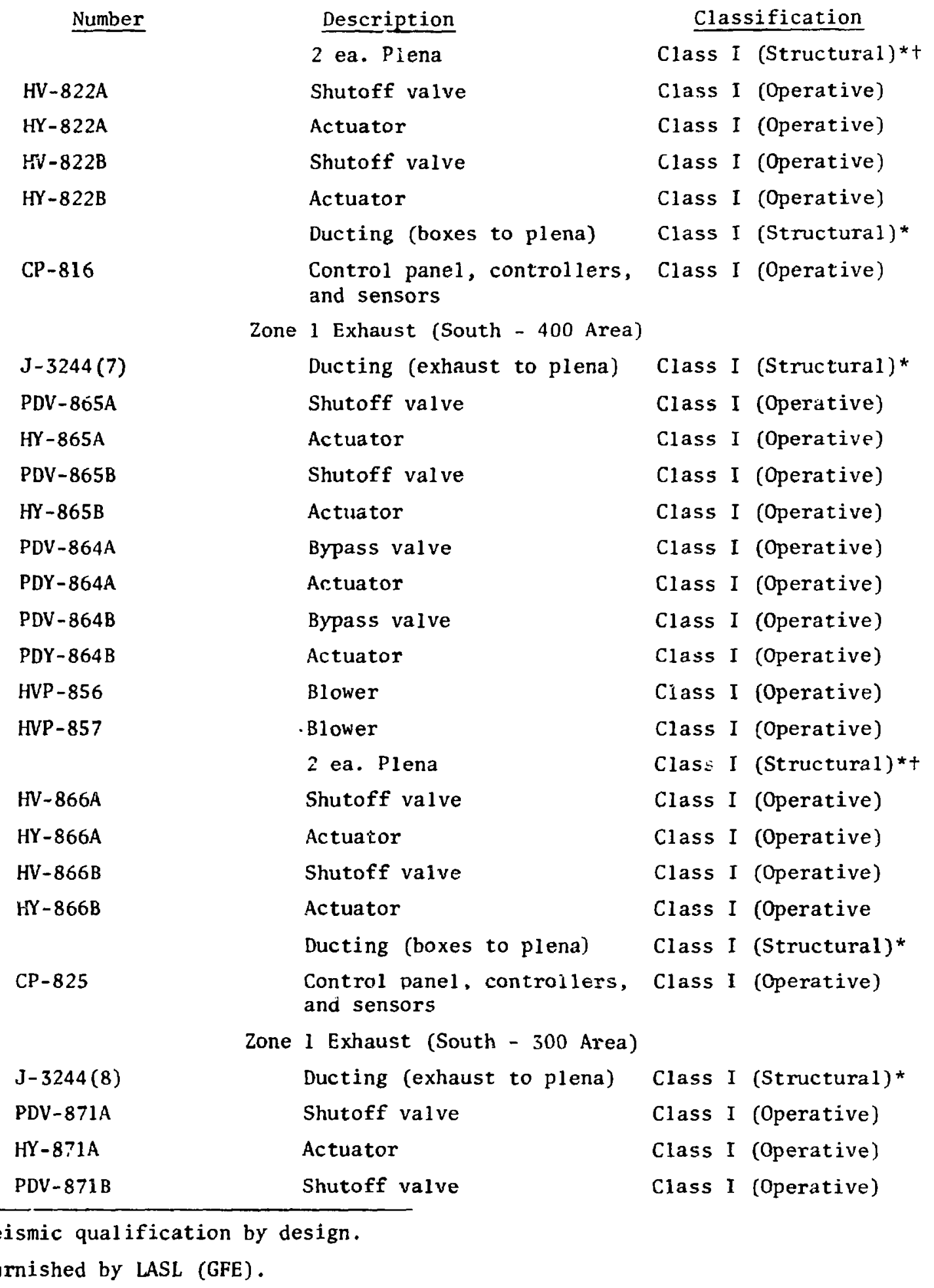




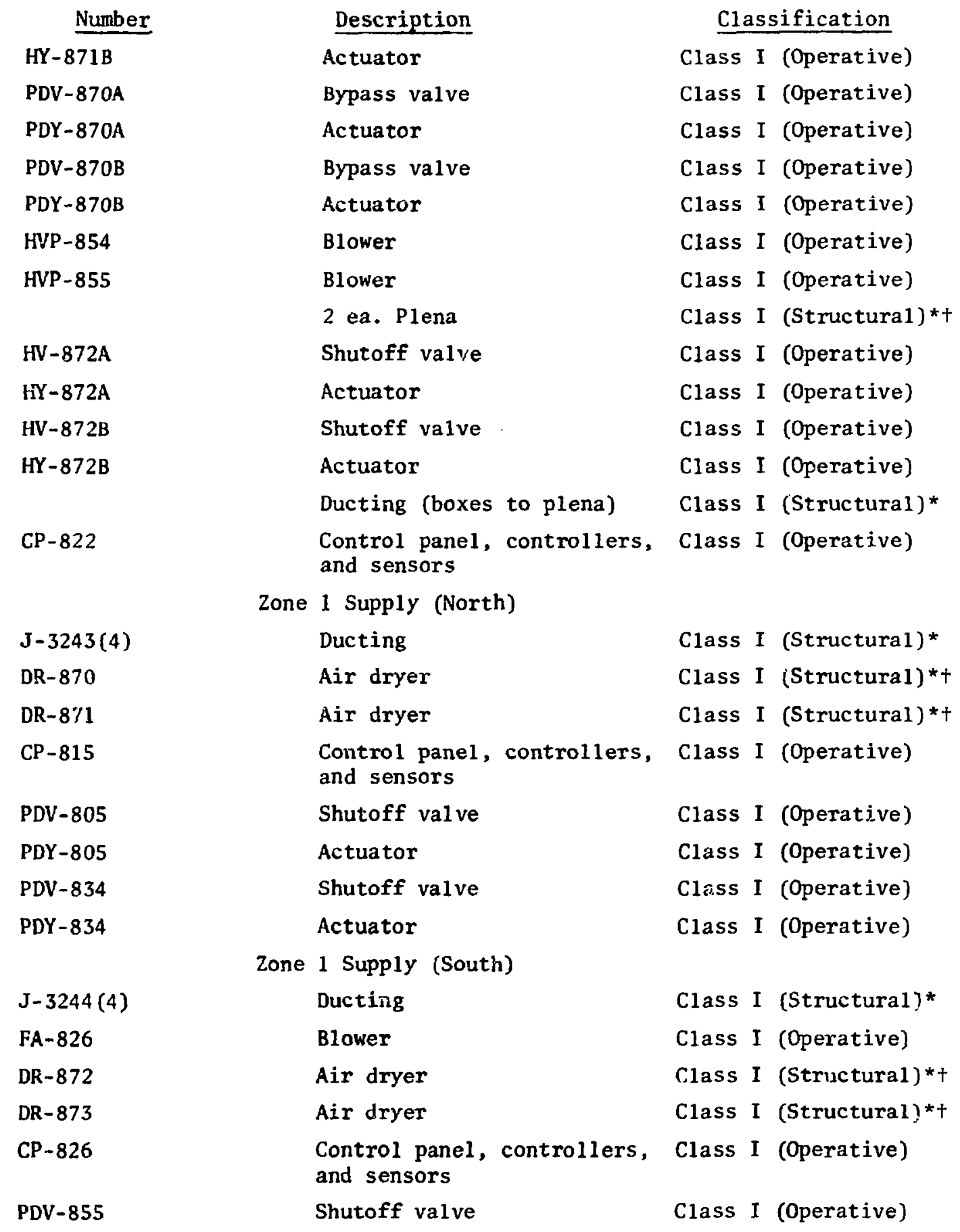

* Seismic qualification by design.

+ Furnished by LASL (GFE) . 


\begin{tabular}{|c|c|c|}
\hline Number & Description & Classification \\
\hline PDY -855 & Actuator & Class I (Operative) \\
\hline PDV -892 & Shutoff valve & Class I (Operative) \\
\hline PDY -892 & Actuator & Class I (Operative) \\
\hline PDV -884 & Shutoff valve & Class I (Operative) \\
\hline \multirow[t]{5}{*}{ PDY -884} & Actuator & Class I (Operative) \\
\hline & Zone 3 Exhaust & \\
\hline & Filter plena & Class I (Structural)* \\
\hline & $\begin{array}{l}\text { Ducting (from filters } \\
\text { to exhaust) }\end{array}$ & Class I (Structura1)* \\
\hline & HEV Control Power System & Class I (Operative)* \\
\hline $\mathbf{J}-\mathbf{3 3 0 0}$ & Control Room Recirculation System & \\
\hline FA- $880 A, B$ & 2 ea. Fan & Class I (Operative) \\
\hline \multirow[t]{2}{*}{ FA- 881} & Fan & Class I (Operative) \\
\hline & Ducting & Class I (Structural)* \\
\hline
\end{tabular}

ISOLATION MOUNTS

Description

Mounts

Tiedowns
Classification

Class per equipment (Structural)*

Class per equipment (Structural)*

* Seismic quaiification by design

\author{
APPENDIX B \\ SEISMIC TEST PLAN \\ DIESEL-ORIVEN EMERGENCY GENERATOR
}

This appendix presents the Test Plan for the Diesel-driven Emergency Generator and is divided into the following exhibits.
Exhibit $B-1$
Test Procedure
Exhibit B-2
Exhibit $B-3$
Exhibit B-4
Exhibit B-5
General Test Requirements
Receiving/Shipping Inspection Sheet
Work Order
Test Schedule
Exhibit B-6
Instrumentation Location 


\section{EXHIBIT B-1}

TEST PROCEDURE

LASL ENGINE-GENERATOR SET

\section{PRESTART INSPECTION}

1. Check overall engine condition. Check liquid levels.

2. Generator: Check overall condition. Check temporary connections for safety and insulation.

3. Control panel: Check electrical connections between generator and breaker panel.

4. Breaker panel: Check electrical connections between generator and control panel.

5. Load bank: Connect to breaker pane1, 3-phase connection with ground to generator set. All voltage change switches are to be in the "UP" or $480-V$ position.

6. Set voltage regulator to "LOW" position.

RUNNING INSPECTION

Check engine instruments and generator instruments. Visually check enginegenerator operation. Allow engine to run without load and check speed control of governor. Check voltage regulator operation and bring voltage up to $480 \mathrm{~V}$. Check underfrequency operation. Check safety shutdown operation. Stop engine, make a visual inspectior, and make any corrections needed.

\section{FUNCT IONAL INSPECT ION}

Bring engine to speed, check instruments, and if all is normal, apply a load of approximately $64 \mathrm{~kW}$. The load bank is resistive, unity power factor. One leg will carry fan motors and will indicate more load than the other legs. The $64 \mathrm{~kW}$ will be $77 \mathrm{~A}$. Allow the engine-generator to remain in this stable condition and $\log$ instrument readings.

Apply an additional load of $64 \mathrm{~kW}$, or bring the amperage to approximately $154 \mathrm{~A}$. Make notations in the $\log$.

Apply final load to the capacity of the load bank. Make notations in the $10 \mathrm{~g}$. Vary lodd up and down to note reactance of the governor and the regulator. Check total operation. This will be the final run and will continue, as needed to verify operation.

\section{ACCESSORIES}

Check operation of engine-mounted accessories, water heaters, lube heaters, prelube pump, day tank, and hand pump. An independent power source will have to be used. 


\title{
EXHIBIT B-2
}

\author{
SECTION I - GENERA.L TEST REQUIREMENTS
}

\section{I.1.0 OBJECTIVES}

I.1.1 Seismic qualification of LASL TA-55 facility hardware by testing to specific postulated earthquake shock levels, as determined by the class of service assigned to each hardware unit.

I.1.2 Determination and identification of resonances in the seismic frequency range of $1-35 \mathrm{~Hz}$ (optional objective).

\section{I.2.0 REFERENCES}

I.2.1 Test Specifications 4401-J-1, Plutonium Building Internals, April 23, 1975.

I.2.2 Extract from Ref. I.2.1, Definitions of Earthquakes, Earthquake Data for Class I, Operative Service.

I.2.3 Resonance Search/Seismic Qualifications, extract from LASL WX-4-63 office memo, dated January 20. 1976.

I.2.4 Work Order, Seismic Testing, LASL, WX-4 (form) .

I.2.5 Inspection Report, Seismic Hardware, LASL WX-4 (form).

I.2.6 Description of shock equipment and capabilities employed in seisnic testing at contractor's facility.

\section{I.3.0 INITIATION OF TESTING}

I.3.1 The work order (Ref. I.2.4), with the upper section properly executed and signed, is the authorization document. It also serves as the accompanying document through testing for recording specifics of the testing procedures.

\section{I.4.0 CLASSIFICATIONS AND REQUIREMENTS FOR HARDWARE (REF, I.2.1)}

I.4.1 Class I Operational requires three $O B E$ and one DBE sequence of tests. Class I Structural requires three OBE and one DBE sequence of tests. Class II Operational requires three OBE and no DBE sequence of tests. Class II Structural requires three $O B E$ and no $D B E$ sequence of tests.

I.4.2 Resonance search and identificat: on: Resonance search(es) will be performed by the random noise technicue (Ref. I.2.3), when called for by the work order, either before, during, or after time-history earthquake sequences.

\section{I.5.0 INSPECTIONS, SHORTAGES, AND DAMAGES}

I.5.1 The seismic testing contractor will perform inspections upon receipt of hardware and again after testing, at the time of reshipment to LASL, using inspection report (Ref. I.2.5) as documentation.

I.5.2 LASL will be responsible for supplying shortages and correcting deficiencies prior to installation on the testing tables.

I.5.3 Inspection report (Ref. I.2.5), bottom portion, will be used for inspection and accountability after reshipment of hardware to LASL. 


\section{I.6.0 PREPARATION FOR TESTING}

I.6.1 Design of mountings and appurtenances to meet or simulate operating conditions shall be the joint endeavor of the seismic testing contractor and LASL, but require LASL WX-4 approval.

I.6.2 Fabrication of mountings and appurtenances shall be the responsibility of the seiunic testing contractor.

I.7.0 WAIVERS

I.7.1 Each waiver of requirement known in advance of testing should be submitted to LASL WX-4 for approval prior to testing.

I.7.2 Unanticipated nonconformance instances should be reported to LASL WX-4 for waiver approval prior to continuation of testing.

1.7.3 Each waiver should be noted on the work order and discussed in the report.

I.8.0 CONDUCT OF TESTS

I.8.1 The tests will be performed by and are the responsibility of the seismic testing contractor.

I.8.2 Functional performance data will be taken, recorded, and evaluated prior to, during, or after testing, as specified by the work order.

I.8.3 Instrumentation used in taking data will be identified with the data taken, whether the data is processed or filed.

I.8.4 Description of test configurations, accessories, or other items, as necessary, may be photographic, illustrations, or by prose--but not redundant.

J. .'j Seismic testing contractor's test plan or operating procedure, if used, should be submitted as part of the contractor's test report, but neither is required.

I.9.0 WITNESSING OF TESTS

I.9.1 LASL WX-4 representative(s) shall witness each test unless waived.

I.10.0 ADDITIONAL TESTING

I.10.1 Resonance search determinations may be required prior to or following time-history earthquake sequences. Such requirements will be annotated on the work order.

I.10.2 When resonances in the $1-35 \mathrm{~Hz}$ range are observed, they will be documented by spectral density plot(s).

I.10.3 Resonances will be corrected only when disqualification is predicted or occurs. Complete retesting is required after correction.

I.11.0 REPORT AND DOCUMENTATION

I.11.1 The seismic testing contractor will furnish LASL four copies of the summary test report, including the following:

A. Work order sheets, executed, as appropriate.

B. Data sheets, as developed during testing.

C. Processed data and results.

D. Listing of nonprocessed data and file record of this data.

E. Discussion of testing, noncompliances, and variances.

F. Brief description of conduct of tests, including photographic record.

G. Certification of qualification/disqualification of items tested.

H. Discussion of resonances, where appropriate.

I. Modifications made to equipment or hardware tested.

J. Contractor's test or operating plan, if used. 
EXHIBIT B-3

SEISMIC RECEIVING/SIIIPPING IINSPECTION

Inspection at test sitc

Sitc U.C. Richmond

Date Received September 1, 1976

Carrier

Cद्qH Transport

Chgs. ppd/coll Prepaid

Hlardware to be Tested MG set for TA-55

Wt. $24,2401 \mathrm{bs}$

Vendor Sandia Detroit Diesel

Address Albuquerque, $\mathrm{NM}$

Properly Labeled___ Yes

Outside Visible Damage ___ None

Opened by

Date September 1, 1976

Contents: Visible Damage____ None

Discrepancies None

\begin{tabular}{|c|c|c|c|}
\hline Part/Item No. & Description & Received & Shipped \\
\hline $\begin{array}{l}\text { MOD } 91237305 \\
\text { MOD E7014DD } \\
4 \text { ea. Group } 8-D \\
\text { MOD A4B-20-24V } \\
\text { MOD } 76-488 \\
\text { ITE } S .0 .50565-D 1\end{array}$ & $\begin{array}{l}\text { Motor generator set, S/N } 12 E 4230 \\
\text { S/N } 1-C-76 \\
\text { Cables, Variac, X-former, circuit breaker } \\
\text { Batteries } \\
\text { Charger, S/N B } 72804 \\
\text { Generator controller, S/N } 7600807 \\
\text { Switch gear }\end{array}$ & & \\
\hline
\end{tabular}

Inspected (In)

Date September 1,1976

Inspected (Out) Date

WX-A INSPLC'ION (Post Test \& ineturn to LASL)

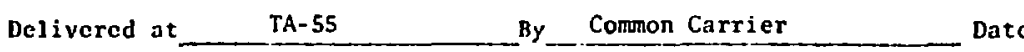

Visible Damage

Other Inspection/Discrepancies

None

Returned to Custody of Sig. Date

Stored at

Signature $(w x-1)$

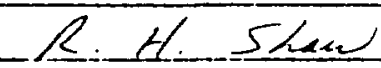
nate

Use seplitate sluec for ablitional information if required. 
EXHIBIT B-4

WORK ORDER

Seismic Testing

LASL- HX-4

REQUESTOR:

Wallace/Brown-01ds/Howard

DATE: $\quad 9 / 14 / 76$

TEST SITE: University of California Earthquake Engineering Research Center, Richmond, CA

PROJECT: TA-55 Internals Seismic Qualification TEST NO. :

SEISMIC LEVEL: Cl.I Operative

SPECIMEN : Diesel engine/generator, batteries, charger and accessorics

PART NO.: 91237305/E701400, Group 8D, A48-20-24V et al.

MFR: Detroit Diesel/Delco (Vendor - Sandia Decroit Diesel)

SIGNATURE:

S/N: See inspection form $w-4: R$ LLWa

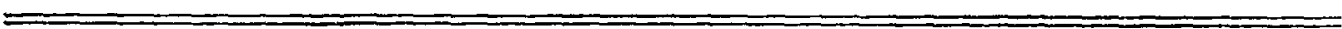

\section{SEC. II SPECIFIC REQUIREMENTS}

SCHEDULED TEST DATE: Nov.-Dec. 1976

PHOTO: $8 \times 10$ color; color motion pictures (by LASL ISD-7)

DOCUMENTATION REQD.: Per General Requirements (attached)

SEISMIC TESTS: 3 ea. OBE and 1 ea. DBE per axis

RESONANCE SEARCH: Required, horizontal and vertical, per contractor's technique

FUNCTIONAL TEST: Pre- and post-seismic sequences, per LASL communication, WX-4-439 attachmen:

IiNSTRUMENTATION: 11 accelerometers, tentatively located per attached sketch.

WAIVERS :

APPROVAL OF WAIVIERS

DATE :

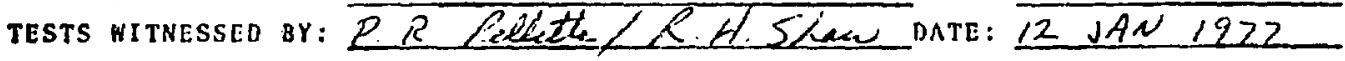

USE SEPARATE SIIETT FOR ADDITIONAL INFORMATION IF RTQUIRID 
EXHIBIT B-5

TEST SCHEDULE

TA-55 DIESEL-DRIVEN EMERGENCY GENERATOR

Day 1 Mount diesel generator set on the table with radiator facing windows in laboratory. Also mount battery box and generator control panel, but not the battery charger or the breaker-transformer unit. Begin electrical connections to diesel generator and installation of accelerometers.

Day 2 Complete work started on Day 1. Calibrate accelerometers and check the operation of the digital and analog data acquisition systems.

Day 3 Perform functional test on diesel generator set. During test, record six selected accelerometers on paper chart continuously and record all the accelerometers on the digital acquisition system for 20-s duration. Perform five tests, using the following table motions:

1. $O B E$ at $50 \%$ intensity on both the horizontal and vertical axes simultaneously. (This test is to check performance of shaking table and data acquisition systems.)

2. OBE at $100 \%$ intensity on both the horizontal and vertical axes simultaneously.

3. Repeat OBE at $100 \%$ intensity.

4. Repeat $\mathrm{OBE}$ at $100 \%$ interisity.

5. DBE at $100 \%$ intensity on both the horizontal and vertical axes simultaneously. Repeat functional test on diesel generator set.

Day 4 Search for natural frequencies by resonance testing in the frequency range 1-20 cps. During resonance testing, the table acceleration amplitudes may not exceed $0.1 \mathrm{~g}$ 's.

Day 5 Rotate diesel generator set so that the radiator is facing control room in laboratory.

Day 6 Perform functional test on diesel generator. Repeat sequence of earthquake motions described under Day 3 . Repeat functional test on diesel generator.

Day 7 Resonance testing as described under Day 4, except search is to be limited to horizontal motion only.

Day 8 Demonstrations for observers and photographer.

Day 9 Remove generator set and associated equipment from table and prepare for shipping. 
EXHIBIT B-6

INSTRUMENTATION LOCATION

Run: 050177:L
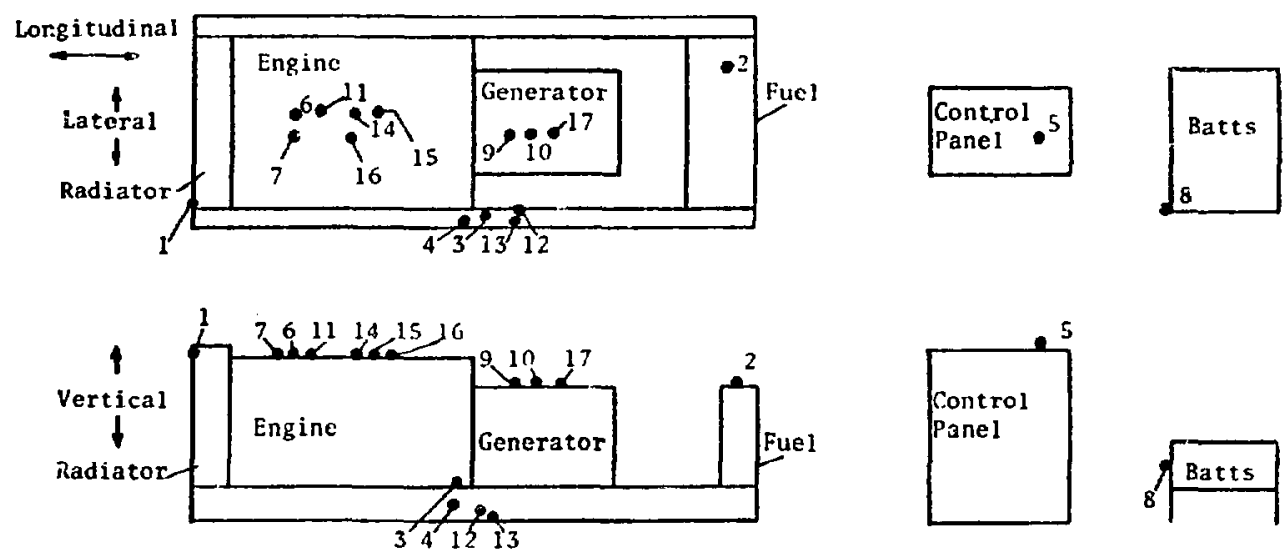

Batts

TABLE - VERTICAL AND LATERAL

\begin{tabular}{|c|c|c|}
\hline EERC & & \\
\hline $\begin{array}{l}\text { Accelerometer } \\
\text { Number } \\
\end{array}$ & Location & Record \\
\hline $\begin{array}{r}1 \\
2 \\
3 \\
4 \\
5 \\
6 \\
7 \\
8 \\
9 \\
10 \\
11\end{array}$ & $\begin{array}{l}\text { Radiator - Lateral } \\
\text { Fuel - Lateral } \\
\text { Frame - Latcral } \\
\text { Frame - Vertical } \\
\text { Control Panel - Longitudinal } \\
\text { Engine - Longitudinal } \\
\text { Engine - Vertical } \\
\text { Batts - Longitudinal } \\
\text { Generator - Lateral } \\
\text { Generator - Vertical } \\
\text { Engine - Vertical }\end{array}$ & $\begin{array}{ll}\text { Channel } & 36 \\
\text { Charnel } & 37 \\
\text { Channel } & 38 \\
\text { Channe1 } & 39 \\
\text { Channel } & 40 \\
\text { Channel } & 41 \\
\text { Channel } & 42 \\
\text { Channel } & 43 \\
\text { Channel } & 44 \\
\text { Channel } & 45 \\
\text { Channel } & 46\end{array}$ \\
\hline \multicolumn{3}{|c|}{ Calibration - Approximately $2 \mathrm{~V} / \mathrm{g}$ 's (use individual calibration). } \\
\hline \multicolumn{3}{|l|}{ WSTHR } \\
\hline $\begin{array}{l}\text { Accelerometer } \\
\text { Number } \\
\end{array}$ & Location & Record \\
\hline $\begin{array}{l}12(1) \\
13(2) \\
14(3) \\
15(4) \\
16(5) \\
17(6)\end{array}$ & $\begin{array}{l}\text { Frame - Lateral } \\
\text { Frame - Vertical } \\
\text { Engine - Latcral } \\
\text { Engine - Vertical } \\
\text { Eng:ne - longitudinal } \\
\text { Genirator - Lateral }\end{array}$ & \\
\hline
\end{tabular}

